\title{
SOCIOLOGIA MODERNA E PÓS MODERNIDADE: LEGITIMAÇÃO E HEGEMONIA NO PENSAMENTO CLÁSSICO E CONTEMPORÂNEO
}

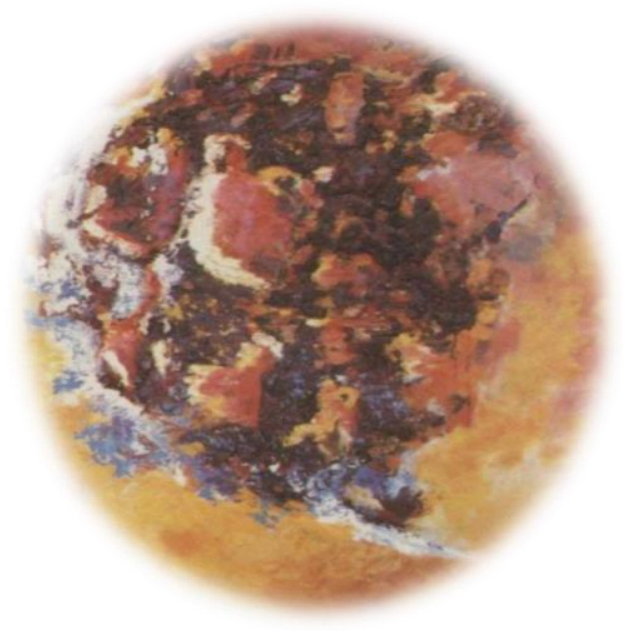

Marilene Corrêa da Silva Freitas

\section{I- INTRODUÇÃO}

Weber e Marx estão entre os clássicos mais influentes do pensamento ocidental moderno, das ciências sociais em sentido amplo, da Sociologia de modo especial, pelo fato de suas teorias de compreensão e de explicação da sociedade constituírem-se em referências fundamentais para o estudo de processos e relações sociais da historicidade do capitalismo, da emergência, expansão e debàcle de socialismo e, ainda, permitirem hipóteses de trabalho sobre as transformações estruturais que dinamizam o caráter das relações internacionais pós-Guerra Fria.

As construções teórico-metodológicas desses pensadores, no entanto, transcendem os fenômenos, as evidências, as ações práticas do mundo real, mesmo tendo estes constituintes da realidade como ponto de partida para seus pontos de vista intelectuais relativos às abordagens do social, e aos valores que implicam conseqüências na apreensão de processos societários. Pode dizer-se que a produção intelectual do porte desses autores, além de fazer parte dos debates contemporâneos, mantêm, com o pensamento social atual, marcantes posições de independência e de aproximações, só aparentemente paradoxais: as formulações de Weber e Marx contêm, em sua originalidade, possibilidades de estudo que 
transcendem os marcos lógico-cronológicos das configurações estudadas por eles em suas obras, permitindo, por conta dessa amplitude e vigor conceptual, ultrapassar os enquadres de tempo e de contexto que sufocam o pensamento no limite de uma época, de uma conjuntura, de um evento episódico.

As teorias de Marx e de Weber, como as dos demais autores considerados clássicos da Sociologia têm sido examinadas com maior ênfase no quadro histórico da formação e desenvolvimento das sociedades nacionais, e, ou, topicamente, em setores especializados da economia, da cultura, da política, relacionados ou não com outros campos e disciplinas das ciências humanas. A partir das discussões sobre o esgotamento ou parcialidade de alcance dos paradigmas clássicos das ciências sociais, as temáticas escolhidas para ratificar, contestar ou situar essas polêmicas têm demonstrado muita vitalidade de proposição e pouca capacidade de resistência. As irrupções de problemas que, de um lado, repõem questões teórico-metodológicas vislumbradas pelos clássicos e, de outro lado, solicitam dos pesquisadores contemporâneos propostas de investigação novas, demonstrou, pela ausência de problematizações ou de respostas, que sequer estas estavam esboçadas como probabilidades, na produção intelectual tópica.

As tendências de análise sociológica pós-moderna só parcialmente não continham perspectivas de estudo sobre a intensificação da economia capitalista em âmbito global e a composição de redes de articulação política e culturais de caráter mundial, que sugerem, pela velocidade, abrangência e singularidade de manifestações, modos de classificação, explicação e caracterização além dos marcos de referência aceitos, e até dos que são apenas tolerados. Isolada ou topicamente, a Sociologia dita pós-moderna estava abordando temas que direta ou indiretamente faziam parte das mudanças exemplificadas, entre outras de grande magnitude. No entanto, parece evidente que uma ausência de articulação desses temas com os processos sociais em transformação retiraram dos discursos sociológicos uma coerência explicativa e compreensiva, como atitude consciente, ao apresentarem-se na forma de pequenos relatos, como fragmentos de fenômenos apreendidos a partir de constatações, impressões sensíveis sobre outros campos, e temas não exclusivos do pensamento social, tais quais os dos avanços da informação, questões da linguagem, dos dispositivos tecnológicos, dos cenários pós- industriais, do cotidiano, sintetizados em seu caráter "cibernético-informático e informacional". Temáticas relativas às 
necessidades de indivíduos e grupos, do ponto de vista ético, político e de direitos humanos da vida privada, de minorias, de ressurgências de etnocentrismos, de preocupações identitárias ligadas ou não às reações de intolerância nacionalistas; questões da cultura na era da informática, também estavam referidas nestas abordagens.

Esta produção sociológica que se posiciona axiològicamente diante da Sociologia clássica, com uma postura de negação às concepções de ciência social desenvolvidas na formação e no desenvolvimento da disciplina e do seu campo autônomo, adota uma atitude intelectual contrária a estes marcos de orientação teórica. No entanto, mesmo assumindo-se contra a produção da Sociologia clássica, total ou parcialmente, não deixa de dialogar explicitamente com as posições e proposições dos seus autores.

Há, nos casos de Weber e Marx, devido ao volume, extensão e fecundidade conceptual de suas obras, um debate que não se esgota em intensidade lógica e ideológica dentro e fora do tempo de suas atuações como intelectuais, e, mais particularmente, no âmbito especializado da Sociologia, com fortes influências e ressonâncias recíprocas em disciplinas afins, como na Antropologia, na Ciência Política, na Lingüística, p.ex.

A rigor tais questionamentos às teorias sociológicas clássicas surgem concomitantes às concepções de mundo que as envolvem. Weber, em seu tempo, travou inúmeras batalhas para distinguir no papel do sociólogo e no campo de atuação do pensamento social, um espaço de legitimidade para a independência intelectual da moral e da política, sem negar a posição de valor na qual o intelectual sempre é passível de se identificar, fator que o leva a considerar a ciência e as instituições científicas como forma e lugar privilegiado de desvendamento do mundo. Marx, nos contextos em que apresentou suas teses a interlocutores situados e identificados no pensamento e na ação social, não escapou dos juízos de fato e de valores provindos de conjuntos teóricos atingidos por suas análises, e além desses, dos grupos de poder controladores da produção e da circulação do saber. O isolamento da repercussão da produção sociológica clássica pelos interesses atingidos pôr ela é, no mínimo, difícil de superar ontem e hoje. No entanto, quando as manifestações de resistências são localizáveis no interior do campo científico propriamente dito, há, pelo menos, algumas possibilidade previsíveis de desdobramentos, para efeito de compreensão de como essas oposições, resistências e tentativas de isolamento são processadas tendo como conseqüências prováveis: 
1) O campo científico se revigora e esclarece-se no plano interno de sua interlocução mediante os recursos lógicos e históricos que dispõe;

2) O conjunto de noções e de conceitos toma novo impulso pela difusão e/ou reformulação teórico-metodológica ampliando sua importância pela vigência social de suas teses;

3) A produção teórico-metodológica é atingida em seu foco central de legitimidade, credibilidade e/ou de hegemonia que se traduz em crises de rupturas e de superação histórica parcial ou total de um campo de conhecimento, dando lugar às disciplinas mais consistentes, ou à emergência de epistemes novas com outros núcleos criadores de pesquisa científica.

O que nos faz supor que as teorias de Weber e Marx guardam relação direta com os problemas atuais do pensamento social, quando a tônica dos últimos anos tem sido contrária à manutenção da importância da contribuição destes autores? O que nos leva supor que determinadas inquietações do pensamento social atual, em sua maioria, ainda contêm reverberações analíticas e conceituais com estes clássicos? Em que medida é possível identificar, de forma velada ou expressa, uma tendência em curso, com muitas resistências, que está configurando uma posição axiológica de revigoração dessas teorias, e, ao mesmo tempo, inaugurando problemas epistemológicos que ainda não estavam postos nas reflexões sobre a realidade pelo pensamento social de hoje? Onde está concentrado o núcleo de críticas contra os chamados modelos compreensivos e explicativos da Sociologia e, até onde eles são passíveis de credibilidade no âmbito acadêmico? Os limites ontológicos atribuídos às formulações dos clássicos referenciados são próprios de suas teorias ou leituras parciais de um ângulo ou de um aspecto que, diante de mudanças sociais inesperadas, produzem reações interpretativas que seriam impossíveis em momentos pretéritos, salvo como utopias?

Este trabalho se circunscreve na apreensão de momentos e aspectos das relações entre a Sociologia clássica e a contemporânea, aqui compreendidas no que se supõe conter elementos centrais dessa discussão, caracterizada como uma oposição entre os alcances e possibilidades dos modelos de análise marxiano e weberiano, vistos como discursos metateóricos, e a crítica que se produz destes modelos pelos teóricos contemporâneos denominados pós-modernos. As perguntas elaboradas, à propósito de introdução ao tema, têm a função parcialmente condutora dos caminhos desta proposta de estudo, e, em si próprias, são indicativas de uma 
inquietação intelectual posicionada, em princípio, por uma "relegitimação" do pensamento clássico, com flexibilidade suficiente para distinguir a postura individual das necessidades postas pelas transformações da realidade.

\section{II- METATEORIAS E PEQUENOS RELATOS: dimensões da modernidade e da pós-modernidade no pensamento social.}

É possível identificar que as concepções de ciência e suas instituições sofrem, a cada modificação sócio-cultural, impactos que alteram a sua natureza. Desde os fins do século XIX, nas primeiras décadas do século XX, os questionamentos de "validação das ciências sociais" recolocavam em outro patamar os problemas de constituição da Sociologia tais quais o seu estatuto científico diante das ciências exatas e da natureza, e em questões ontológicas que envolviam a dinâmica da cultura, e o novo lugar da ciência nas expressões e representações do mundo contemporâneo, agora envolvidos pela e na teia das transformações tecnológicas.

O que parece estar em causa na crise da ciência, que se agudiza nos anos 50, é a "crise" de um modo determinado de referendar a razão científica. O que se expressa hoje, de forma mais contundente, em relação aos modelos teórico-metodológicos clássicos, guarda, até certo ponto, uma relação de origem com os vários momentos de formação da Sociologia como disciplina autônoma, portanto com a delimitação de objetos e métodos próprios em face da especificidade do social. A filosofia das Luzes, as ideologias revolucionárias que incluem os chamados precursores, o positivismo e suas vertentes, distinguiram, desde as formulações pioneiras, as caracterizações doutrinárias, cientificistas, experimentalistas, mais ou menos inclinadas à lógica formal ou à classificação organicista que envolviam o objeto de estudo da Sociologia. Em Comte, já existiam questões que sobreviveram à chamada "crise de paradigmas" nas ciências sociais: a absolutização das noções sobre os fenômenos sociais era um risco a ser evitado; a necessidade de o cientista social ser um explorador do universo de pesquisa no campo da sociedade industrial em consolidação era urgente frente as rápidas transformações; um compromisso intelectual de empenho pela descoberta de leis e processos que movimentam e estabilizam o todo social era o princípio que asseguraria um domínio mínimo sobre o objeto de 
conhecimento; e, ainda, a necessidade de respaldar o conhecimento sociológico na sistematização de raciocínios e na observação cuidadosa.

A crítica da razão, hoje, esquece que até para Comte o confronto entre o empirisimo e o racionalismo não era uma questão prioritária, assim como ele não estava preocupado em postular uma unidade de pensamento e de ação para o pensamento social, mesmo indicando a conveniência de a abordagem científica ser realizada por ordem crescente de dificuldade "da matemática à biologia, que marca um importante ponto de inflexão, - já que - com ela - o ponto de vista científico deixa de ser analítico para se tornar sintético" (Cuin e Gresle, pp. 31-33).

No entanto, o diálogo dos anos 80 com a Sociologia clássica que tem a intenção de demonstrar seu esgotamento pela "deslegitimação" do referencial explicativo de seus recursos lógicos e históricos, atribui, à qualidade de os pensadores modernos recorrerem a produção de um metadiscurso filosófico para legitimar, além dos enunciados genéricos e utilitaristas em sua busca de verdades, as regras do jogo que lhe assegurem credibilidade. "Quando esse metadiscurso recorre explicitamente a algum grande relato, como a dialética do espírito, a hermenêutica do sentido, a emancipação do sujeito racional ou trabalhador, o desenvolvimento da riqueza, decide-se chamar "moderna" a ciência que a isto se refere para se legitimar" (Lyotard, 1990, xv).

As reflexões de Lyotard não brotam de um "vazio" referencial; são reverberações do pensamento de Weber e Marx mediatizadas por outros pensadores que chegam até às inquietações da Sociologia pós-moderna. No sentido positivo, os modelos de análise construídos por eles foram tomados como chaves compreensivas e explicativas para as revoluções materiais e espirituais dos séculos XIX, XX, com perspectivas de vigência nas transformações em curso para o século XXI. Sob a forma de diálogo ou de polêmica, a ponte que é estabelecida entre o pensamento social clássico e o contemporâneo implica em que o saber e o agir guardam relações atuais, criam ou abrem portas com os conceitos e categorias desenvolvidos por Weber e Marx. Ambos são pensadores da modernidade, ambos são portadores de uma disposição intelectual livre de outros limites imaginários que não fossem os movimentados pela Razão. Marx exacerba a razão Iluminista; Weber é o pensamento social moderno em crise, componente e constituinte de um pessimismo iluminado; ambos iriam sustentar formulações intelectuais fecundas, num diálogo de transição entre as 
elaborações clássicas e a polêmica que os teóricos pós-modernos travam com eles e através de suas referências analíticas. A escola de Frankfurt é a expressão mais fina desse diálogo de transição que prenuncia ou antecipa a destinação do pensamento científico e de suas instituições no mundo articulado pela razão instrumental que, em embate com a razão emancipatória, seria, também, um dos componentes da polêmica dos modernos com os pós-modernos.

A ilustração dessa transição tem em Benjamin, exemplos de grande intensidade e beleza intelectual e estética, ainda vinculados à razão Iluminista, mas num processo crescente de desesperança de a humanidade ser integrada pela emancipação, nos limites concretos que não a deixavam dar um novo passo positivo em sua evolução. A versão frankfurtiana de modernidade articula o conceito de racionalização do modelo weberiano com as categorias ontológicas e epistemológicas do materialismo histórico e dialético, sem submissão cega às referências citadas, produzindo uma apreensão atualizada dos fatos sociais do seu tempo com os modelos clássicos, e com os dilemas que desafiavam os intelectuais nos primeiros anos do Século XX.

A vida moderna se constrói na crescente racionalização dos fatos sobre as convicções. Os fatos invadiram todos os âmbitos dos valores; até a atividade literária teve suas molduras quebradas pelos novos fundamentos factuais. Fatos tais que constituem o lugar ou o motivo da criatividade artística, e induzem a atuação literária a fazer-se significativa pela produção de uma "linguagem de prontidão", à altura do momento. A vida social é uma "máquina gigante" onde, para irrigar o seu mecanismo com o "óleo das opiniões", torna-se necessário conhecer suas juntas, rebites, dobraduras. O usuário do "posto de gasolina", imagem que Benjamin cria para o sujeito que quer conhecer as juntas ocultas da máquina social, não pode borrifar suas opiniões de qualquer forma, como não se pode jogar óleo diante de uma turbina. O homem moderno não pode confiar nem aferrar-se "naquilo que é capaz (...) sem trair-se à si mesmo” (Benjamin, Posto de Gasolina, p. 15).

O homem moderno perdeu ou mal conhece a experiência cósmica, ao contrário do homem antigo que a tinha como elemento de sua existência. A astronomia anunciou o naufrágio da experiência cósmica, no começo da Idade Moderna e, no entanto, não era apenas o impulso científico que movia Kepler, Copérnico, Tycho Brahe. A vinculação ótica exclusiva com o universo fez a astronomia conduzir à emergência de um "signo" precursor do que viria: o trato antigo com o cosmo cumpria-se de outro modo, na 
embriagues. (c.f. Benjamin, A Caminho do Planetário, p.68). A experiência da embriagues recupera o sentido de comunidade e nos assegura da presença, da distância, mas nunca da ausência do próximo, do semelhante. A impossibilidade de o homem moderno se comunicar com o cosmo é ameaçadora, é um descaminho considerar irrelevante ou descartável uma experiência da humanidade que está, ainda, nos seus primórdios. O indivíduo não é capaz de dar conta dela em seus devaneios, e, quando essa possibilidade é posta diante de si, o que deveria ser um grande passo da evolução, transforma num "mar de sangue" o encontro da humanidade com o cosmo que deveria ser idílico. A humanidade foi traída pela técnica. O encontro da experiência cósmica com o homem moderno mostrou o verdadeiro sentido da técnica de dominação da natureza em escala planetária, durante a Segunda Guerra mundial. Apropriada pela classe dominante, a relação entre a natureza e a humanidade foi apunhalada pela vontade dos interesses de “avidez de lucro". No começo da vivência humana planetária a Mãe Terra foi revolvida em todas as suas entranhas; mares, ares, superfície, subterrâneo, foram atravessados por gases, forças elétricas, aeroplanos, submarinos, ferveram propulsores, cavaram e rasgaram poços e sulcos sacrificiais nas profundezas do globo. A técnica organiza uma nova phisis, um novo corpo, uma nova forma de a experiência cósmica encontrar o homem. O ensaio desse indivíduo na experiência desconhecida do encontro da humanidade com o cosmo pode ser comparada à felicidade do epiléptico em convulsão, onde a técnica dispõe de um novo corpo para o exercício de seu poder. (...) "A potência do proletariado é o escalão de medida de seu processo de cura. Se a disciplina deste não penetra até a medula, nenhum raciocínio pacifista o salvará. $\mathrm{O}$ vivente só sobrepuja a vertigem do aniquilamento na embriagues da procriação" (Benjamin, o.p.cit., pp. 68-69).

O caráter do homem moderno pode ser representado na destruição. As pessoas que a encarnam tem algumas características do seu modo de ser, do seu estilo de atuar: alegre, jovial, "tem como lema a criação de espaço e como atividade despejar". É apolíneo, está sempre trabalhando, tem pouca necessidade de idealizar imagens; evita o criativo e, ao contrário do criador que precisa de solidão, o destruidor necessita de pessoas que o rodeiem e atestem sua eficiência. $\mathrm{O}$ caráter destrutivo não tem interesse em ser bem ou mal compreendido. Assim elimina a bisbilhotice e não fomenta o mexerico; está no front dos tradicionalistas. É adversário, destruidor e eliminador do homem-estojo, daquele que busca comodidade no interior de uma caixa revestida de veludo, como síntese do caráter que deu ao "seu mundo". O caráter destrutivo é volátil, abridor de caminhos onde outros esbarram em 
obstáculos; tem consciência do homem histórico cujo sentimento básico é a desconfiança; à qualquer momento, tudo pode acontecer de mal. "Por isso o caráter destrutivo é a confiança em pessoa;(...) é um sinal. Como símbolo trigonométrico está exposto ao vento por todos os lados [.] Protegê-lo não faz sentido" (p. 235). O caráter destruidor é refinado e sutil, mesmo sabendo de que é um abridor de muitos caminhos está sempre diante de uma encruzilhada. Não sabe o que vai encontrar no próximo passo, nem o que vai encontrar no próprio caminho, por isso, o caráter destruidor cria ruínas por onde consegue passar e por causa deles. Deste modo "não vive do sentimento de que a vida vale ser vivida, mas de que o suicídio não vale a pena” (Benjamin, O Caráter Destrutivo, pp. 235-237).

A modernidade pós-guerra atualiza diariamente o encontro do indivíduo com os fatos e acontecimentos do globo. Notícias à cada manhã tornam inexplicáveis a pobreza de histórias notáveis, hoje. Por que? Não deveria ser o contrário? Se os antigos produziam histórias que até hoje causam admiração e reflexão, isto pode significar que a arte de narrar tem um segredo muito simples na ausência de palavras explicativas. Os mestres da narrativa antiga, Heródoto à frente, cultivavam este segredo. Ele explicou sem uma palavra o sentido da atitude do rei Psamético, derrotado e aprisionado pelo rei dos persas, Cambises, que resolveu torturá-lo humilhando seus filhos e um servo egípcio. A impassividade do rei foi mantida ao ver a filha passar na condição de serva, ao ver o filho caminhar para a execução, mas, ao ver seu velho e fiel servo como prisioneiro, manifestou o desespero que sentia golpeando a cabeça. Aqui parece residir o encanto da narrativa antiga. Um jornalista de hoje, num piscar de olhos faria publicar em todos os jornais que o rei Psamético amava mais ao criado do que aos seus filhos, diz um comentarista. E dia seguinte outros fatos recobririam o fato anterior, sem lembrá-lo, refleti-lo, admirá-lo, especulá-lo. A pobreza humana de histórias notáveis está no fato de que nenhum evento é publicado "sem estar impregnado de informações". Tudo beneficia o momento, a informação nova, a novidade deve se entregar totalmente ao efêmero, "e sem perder tempo, à ele se explicar". A narrativa perdeu a sua arte uma vez que parte dela, ou seja a sua metade artística consistia em manter a transmissão da história livre de explicações. Hoje, dá-se o contrário: “quase nada mais do que acontece beneficia o relato; tudo beneficia a informação". No entanto, se a informação vive do momento, a narrativa verdadeira conserva uma "força em seu âmago e é capaz de, após muito tempo, se desdobrar" (Benjamin, Contar Arte, pp. 276-277). 
A gênese das grandes obras refletidas na imagem do nascimento é uma visão dialética da obra, da relação do autor com a criação, e da recriação do autor pela obra. Esse processo, de um lado, refere-se à concepção criativa, no temperamento, no feminino, cujo fator se esgota na conclusão. "Dá a vida à obra e então se extingue". Do outro lado do processo a conclusão da obra não é uma coisa morta; o que morreu foi uma parte dela, a sua concepção; conserva-se nela, a parte da conclusão que é viva, que não se esgota, que conduz a um processo interior de "polimento e aprimoramento" que não pode ser extraído à força. "Trata-se, então, de um outro nascimento quando em sua conclusão, a criação da obra torna a parir o criador (...) agora no seu elemento masculino". O criador ultrapassa a natureza, está além do útero materno que gerou a sua existência originária, pela concepção gerada por outro tipo e modo de criação. Agora, ele, o criador, "é o primogênito masculino da obra, que foi por ele concebida" (Benjamin, Pequenos trechos).

Sobre a Arte, in Após a Conclusão, p.277).

A crítica da Sociologia moderna tem, em princípio, formulações diversas. As mais amplas, nos campos epistemológicos, ontológicos, gnosiológicos, e as mais restritas, opõem os grandes aos pequenos relatos, o individualismo metodológico ao pluralismo impressionista, as abordagens privilegiadoras da ação individual aos sujeitos coletivos, às perspectivas emancipatórias de grupos, coletividades e classes.

A atitude ceticista de suspeita diante de teorias e métodos de ação social efetiva-se através de formulações de médio e pequeno alcance. Pode dizer-se que o Positivismo e o Materialismo Histórico são pensamentos da modernidade; as teorias compreensivas e niilistas de Weber e Nietzche expressam a crise do pensamento social e de seus limites modernos; Freud e a psicanálise inauguram outra dimensão do pensamento na fronteira com as perspectivas de análise pós-modernas. Mais, para além das classificações rígidas, todos os autores citados podem ser considerados modernos, no sentido de que expressam um modo de ser, um estado de espírito peculiar diante da sociedade e dos fenômenos que desmistificaram, desvendaram, dessacralizaram (Ianni, 1995, comentários sobre o tema Modernidade pósmodernidade). 
É sobre essa tradição Iluminista que a crítica pós-moderna incide com maior vigor; nos casos de Weber e de Marx, especialmente do último, pelo fato de sua tradução da filosofia das Luzes em ciência social constituir a interpretação mais radical da razão emancipatória, explicando, em parte, porque todas as vertentes do pensamento pós-moderno mantêm, com ele, um diálogo tão drástico quanto abrangente.

A configuração desse diálogo é complexa e precisa ser situada nas críticas mesmas da modernidade e de suas representações na imaginação científica: vê-las como um modo de liderar a criatividade intelectual, vê-las como um complicador das relações sociais aparentemente naturais, vê-las como um processo civilizatório da historicidade do capitalismo, vê-las de forma articulada às elaborações filosóficas, artísticas, científicas é reduzir o risco de analisar uma modernidade abstrata; é resistir às tentações de desvinculação das noções de totalidade que presidem as mediatizações do pensamento social moderno.

Há irrupções de modernidade em contextos mais adversos. A arte, p.ex., em sua variedade de manifestações, pode anteceder cenários que ainda não existem no momento da concepção artística. Benjamin refere o exemplo do romance do crime que começa com Poe, onde está embutida a prescrição da vítima e o itinerário da fuga do criminoso, na disposição dos móveis e dos cômodos. "O centro do terror é a casa".(...) Pois os grandes escritores, sem exceção, fazem suas combinações em um mundo que vem depois deles, como as ruas parisienses dos poemas de Baudelaire só existiram depois de 1900 e também não antes disso os seres humanos de Dostoievski” (Benjamin, Casa Mobiliada, p. 15). Ser moderno é ser volátil, é identificar-se com o movimento e a transformação. É nessa hipótese que a modernidade pode ser explicada por movimentos da cultura universal. A síntese do espírito da modernidade compreende a Razão como guia da vida material e moral; a anulação ou redução dos valores e explicações tradicionais; e, o aparecimento de instituições ordenadoras do saber que dão credibilidade e legitimidade aos enunciados da verdade, da Razão, do conhecimento científico.

O que se põe em causa na crítica pós-moderna é a superação da Razão Iluminista: as possibilidades de emancipação do sujeito foram derrotadas em nível micro e macro; houve uma ruptura no âmbito da arte; as conquistas da modernidade são postas como suspeitas pela subjetividade e pela história. A Razão não ordena o mundo pós-moderno, nem o mundo da história, nem o mundo natural. O espírito da modernidade pode se 
traduzir numa atitude de apreensão do mundo como realidade fragmentada, descontínua, desencontrada, cheia de impasses. O espírito do mundo pósmoderno nega os nexos, os sentidos, as contradições como articuladores de signos com os quais se identificam como linguagens: a bricolagem, a montagem, a colagem, o virtual, o pequeno relato, o simulacro, entre outras formulações pós-modernas, também podem ser vistas como momentos e movimentos não codificados da modernidade. Outras manifestações de produções materiais e espirituais podem ser expressas como dimensões pósmodernas propriamente ditas, mas não exclusivas, porque também indicam um mundo articulado pela razão instrumental (cf. Ianni, 1995, op. cit.).

Há um núcleo de críticas pós-modernas ao pensamento clássico que inclui essas formulações como ilusões sem mitos e sem deuses que, à cada momento de reflexão sobre a realidade acrescentam uma volta à espiral do simulacro, imagem da deslegitimação da racionalidade científica, naturalista, materialista, lingüística e psicanalítica. A racionalidade, neste núcleo de críticas, e apesar da variação de discursos, incide num modelo epistemológico universalizante e transitório. Baudrillard é um dos representantes da crítica pós-moderna fora do enquadre frankfurtiano que, mesmo retomando pontos temáticos identificados em Benjamin, formula uma teoria anti-Iluminista para incluir Marx, Weber, Freud e Saussire, no mesmo movimento que aperfeiçoa e prolonga a filosofia do Esclarecimento - fundamento do simulacro naturalista-, através de uma outra metáfora da Natureza como, TOTALIDADE, o materialismo histórico. O conceito do modo de produção permite aos materialistas produtivistas acrescentar uma outra volta à espiral do simulacro e transcender às determinações particulares do espaço-tempo em que foram geradas (cf. Baudrillard, p. 40).

Essa projeção da reflexão da cultura ocidental através da metafísica é de uma eficácia ideológica incontestável, ao lançar no universal o que era próprio do seu caráter, da sua especificidade. Este é o sentido em que Baudrillard confere ao materialismo histórico a consideração de uma teoria especular, uma vez que o modo de produção capitalista, objeto desta teoria, preserva, intacto, o princípio da produção enquanto simulacro: (...) “produção textual, EROS produtivo, ETHOS produtivo em tudo é reduzido ao mesmo denominador comum, seja a riqueza social, seja a linguagem (cf. p. 40-41)".

A contrafação, a produção, a simulação são as três ordens de simulacros que a Idade Moderna inaugura através de uma composição que 
associa valores e significações e representam a evolução do imaginário na cultura ocidental. A história dos sistemas de representação do pensamento no Ocidente toma como ponto de partida o aparecimento do SUJEITO e o seu descolamento da comunidade, marco da emergência autônoma da vida societária.

A ordem do valor-signo inicia a modernidade quando extingue, exclui ou destrói a ordem simbólica. Da oposição inicial e paradigmática operada pela disjunção entre vida e morte, outras oposições são assinaladas em cada passagem da espiral dos simulacros em diferentes formas de desdobramentos visando superá-las. O impasse "desencadeado em cada movimento de disjunção das oposições", cujas conseqüências podem ser desde o aniquilamento, às contrapartidas, a absolutização, componentes da cultura contemporânea que desenvolve nessa trajetória em espiral, uma obsessão iconoclasta, a expressão mais fidedigna da ordem valor-signo da modernidade: "a teoria do reflexo (e mais particularmente, o materialismo histórico, a psicanálise e a teoria do signo)" [...], segundo Baudrillard (Melo, 1988, p. 14).

A "lei natural do valor" é a abstração que se segue das trocas simbólicas, do sistema de dádivas, quando a cultura ocidental passa a representar-se à si própria, com um ciclo imaginário que coincide com a configuração da individualidade, da ascensão da burguesia, da emergência do Estado moderno, uma era onde o indivíduo é o pólo da alteridade na relação sujeito-objeto. A posição do sujeito-observador é marcada pela perspectiva arquitetônica do Renascimento a partir de um local privilegiado onde o efeito de profundidade é proporcional à distância do espectador. A criação do simulacro naturalista configura-se na cidade estelar com um edifício de planta central simbolizando um observatório posto no ponto focal. À esta lei corresponde o significado da contrafação que transforma a competição pelo prestígio social do seu caráter ritualístico e cerimonial, signo das sociedades simples, arcaicas e feudais das comunidades, castas e estamentos, em signos arbitrários e abstratos, pela eliminação da reciprocidade e pela transformação da relação dual em um sistema formal de troca indiscriminada entre uma e outra classe. Os signos anteriores, diante de um estatuto novo que predomina "soam estrangeiros", falsos, porque evocam uma presença ausente.(...) "O signo moderno sonha com o signo anterior, e desejaria, com sua referência ao real reencontrar uma obrigação: ele não encontra senão uma razão: é essa razão referencial que ele vai viver" (Baudrillard, 1976, p. 78). A era da mimese da natureza precede o estágio da produção, esta 
primeira redução do natural à representação do signo consolida-se com a Contra-Reforma, com um modo de organização racional e, simultaneamente, numa hegemonia política, com uma disciplina mental e uma concepção moderna de poder (a concepção jesuítica) que tem, em suas origens, a abstração da substância natural e a sua redução à substância síntese.

A ordem da produção corresponde à era industrial e à lei mercantil do valor. Realiza-se, nesta leitura, o segundo movimento da espiral dos simulacros: o da intervenção e transformação efetiva da natureza onde o autômato do primeiro simulacro, composto no aparato e no teatro do espaço clássico, é aperfeiçoado pela reprodutibilidade técnica da máquina, do robô, ultrapassando o original. Se no autômato a diferença entre ser e aparecer permanece intacta, permitindo a identificação do robô, a máquina, é um equivalente do homem e sua semelhança representativa com o autômato é apenas a aparência de uma diferença fundamental "que é o processo de reprodução ou a diferença entre a simulação encantada e a simulação desencantada". A dúvida entre o falso e o verdadeiro da era clássica da contrafação agora desaparece. O robô, substituto do criador funde-se no ser e no aparecer, o simulacro e o real são sintetizados. Opera-se, concomitante, uma mudança radical no conceito de Natureza do século XVII como o das leis fundantes da inteligibilidade, para o conceito produtivo que opõe o Sujeito e a Natureza. A Natureza do Esclarecimento do século XVIII é o conceito de uma "essência dominada" que contém, ao mesmo tempo, em cada produto de trabalho, um signo da natureza operável, uma representação do ato da operação. "Por um artifício da ideologia é que os termos tornamse permutáveis: a operacionalidade da natureza é contemporânea da naturalidade da produção". É essa natureza/produto/mercadoria que se torna no Grande Referente, permitindo o esboço histórico conceptual da segunda ordem de simulacro que é a PRODUÇÃO como conceito ambíguo, engendrado pelo pensamento burguês do século XVIII, efetivado como essência abstraída pela Técnica e pela Ciência, justificando esse processo de transformação pela constituição da natureza como finalidade. Isto permite articular a Natureza como Fator de Produção e como modelo de finalidade, definindo-a como abstração e, nessa instância, constituindo-a em METÁFORA da TOTALIDADE e da LIBERDADE.

O Iluminismo cria um conceito de natureza que dá legitimidade ao novo movimento na espiral do simulacro que é caracterizado pela lei estrutural do valor, no estágio de desenvolvimento capitalista de sociedades 
avançadas que toma a sua forma mais desenvolvida no CÓDIGO, dimensão emblemática da modernidade (cf. Melo, pp. 15-40).

A dessacralização da contrafação tradicional agudiza a importância teórica da metafísica marxista, na avaliação de Baudrillard, porque a produção, ao representar um momento episódico na trajetória dos simulacros é reforçada por Marx, como se a perenidade do modo de produção desse vigor à ficção do HOMO ECONOMICUS e à ilusão produtivista, ao invés de por fim nessas simulações.

A ficção do valor e da finalidade da produção são para Baudrillard o paradigma em que o materialismo histórico se ampara para estruturar todos os setores da vida humana : "O ser em si" é substituído pela ficção "de produzir-se a si mesmo". A teoria especular em que a caracterização materialismo histórico feita por Baudrillard se desenvolve é, na verdade, a retomada de uma sugestão de Benjamim onde essa especularidade está sugerida na alegoria que reúne as imagens do espelho e do autômato, onde a crítica de Baudrillard apreende a eficácia teleológica de o espelho da produção reforçado por Marx permitir a "tomada de consciência da espécie humana no imaginário, através de representações que fazem emergir um mundo pretensamente objetivo" (Bruzzi, 1988, p.41) no qual o homem se reconhece como algo a ser investido e transformado. O homem é para si próprio o que significa passando a compor uma identidade formal entre a ordem da produção e da representação, que em si mesmas, são inseparáveis; o que não o absolve de uma redução (do homem) e uma cumplicidade (com o modo de produção) e não são tratadas na análise marxista de modo radical. Bruzzi, ao comentar essa relação entre Baudrillard e Benjamim, cita um trajeto do trecho onde a passagem desta alegoria está identificada.

(...) Conhecemos a história de um autômato construído de tal modo que podia responder a cada lance de um jogador de xadrez com um contralance, que lhe assegurava a vitória. Um fantoche vestido à turca com um narguilé na boca, sentava-se diante do tabuleiro, colocado numa grande mesa. Um sistema de espelhos criava a ilusão de que a mesa era totalmente visível, em todos os seus pormenores. $\mathrm{Na}$ realidade, um anão corcunda se escondia nela, um mestre no xadrez, que dirigia com cordéis a mão do fantoche. Podemos imaginar uma contrapartida filosófica desse mecanismo. O fantoche do 'materialismo histórico' ganhará sempre. Ele pode enfrentar qualquer desafio, desde que tome à seu serviço a teologia. Hoje ela é reconhecidamente pequena e feia e não ousa mostrar-se [Cf. Benjamin, 1986, 
p.222. (Obras: Majue, Técnica, Arte e Política, trad. de Sérgio Paulo Rouanet. São Paulo, Brasiliense, 1986. Obras Escolhidas, volume 1)].

Reducionismo no plano ontológico, valorização produtivista no plano teológico, redução ao mesmo denominador comum da riqueza social e da linguagem são acréscimos a outras críticas que Baudrillard atribui à Marx e, também, ao materialismo dialético, pelo fato de situá-lo tanto quanto os conceitos e categorias do materialismo histórico no âmbito da ordem das representações e, portanto, com caráter de reduplicação do objeto de projeção e do movimento da economia política no imaginário, transformando a produção teórica em "espelho da produção", pelo fato de a representação teórica da produção ser, enquanto espelho, simulacro. Baudrillard constrói, assim, um núcleo articulado de críticas à perspectiva marxiana clássica, através de um conjunto de conceitos e formulações internas e externas às referências analíticas de Marx. $O$ uso da noção da estrutura binária feita por Marx atribuída em sua análise por Baudrillard apóia a sua avaliação de que a composição do seu discurso tem base na REDUPLICAÇÃO dessas estruturas; nas relações dialéticas entre o abstrato e o concreto, trabalho e forma-valor, que correspondem à separação entre a representação científica e o movimento real. A relação dialética entre a teoria e o objeto que existe efetivamente, e não apenas no marxismo, mas que não o isenta, encerra ambos no que Baudrillard chama de "especularidade intransponível". Poster, na análise de Bruzzi, ao aproximar Habermas e Baudrillard assinala que as críticas que estes fazem às relações entre tecnologia e cultura em Marx incidem em que suas análises sobre às relações de trabalho e a produção da vida material, "são omissos e deficientes quanto à interação simbólica e, principalmente, quanto ao papel mediador da linguagem" (cf. Poster, 1981, p.458; Bruzzi, 1988, p.42, nota 40).

Em resumo esta nucleação de críticas de Baudrillard nos planos ontológicos e epistemológicos em Marx enfatiza:

1) A duplicidade e a generalidade do estatuto ontológico do HOMEM do conceito de produção como movimento universal. O homem força de trabalho e simultaneamente necessidade é uma construção abstrata da economia política tanto quanto a produção consuma-se numa produtividade abstrata e generalizada, ao ser um duplo de princípio determinante do modelo teórico marxista, e um constituinte do desenvolvimento da humanidade como força produtiva do capitalismo. Para 
Baudrillard estas características do pensamento de Marx indicam a sua extrapolação do econômico para o METAFÍSICO;

2) As construções teóricas de Marx extrapolam os limites das oposições e contradições reais. Assim a alienação do homem reduzido à força de trabalho é ainda mais radical do que a venda da força de trabalho mesma;

3) A teleologia marxista é fundada pelo conceito determinístico do modo de produção, quando "toda uma civilização se representa como produtora de seu próprio desenvolvimento" para realizá-lo enquanto finalidade. A racionalidade do econômico compromete todo o devir humano quando este a assume e submete todas as manifestações da vida cultural a este racionalismo produtivo. Para Baudrillard a crítica de Marx sobre a formação e o desenvolvimento do capital é mais sofisticada e refinada do que a realidade do sistema capitalista. Assim, sua crítica não é senão uma legitimação da ordem do capital e transforma o materialismo histórico numa "ideologia da ideologia", portanto num simulacro de segunda ordem;

4) A categoria trabalho é o cerne da apreensão do homem do processo de auto- produção, de auto-objetivação e de objetivação da natureza. $\mathrm{O}$ trabalho concebido dessa forma guarda relação com a ética cristã e com a ética protestante de Weber. É nesta categoria que Marx centra a relação dialética homem/natureza onde a ação humana exterioriza-se; Weber concebe no trabalho a ascese intra-mundana que se realiza no esforço e na superação dessa relação. Baudrillard vê, aqui, uma relação ontológica entre Marx e Weber, ambos circunscritos na tese produtivista em que o "trabalho é condição necessária dessa exteriorização"; na análise weberiana constituise como matriz ideológica do sistema capitalista. Weber tem uma visão positiva do trabalho na ética protestante; Marx tem uma visão de negatividade assumida sob a forma aristocrática em que concebe o trabalho. “ss، “ss، Há, em ambos, uma comum vocação produtiva do homem, uma metafísica oriunda da mesma ontologia, não havendo diferenças radicais entre a perspectiva weberiana enquanto "uma religião de massa" e o marxismo" científico" que se funda numa teoria filosófica;

5) Os limites epistemológicos do materialismo histórico remetem à aceitação do conceito natureza em Aristóteles, explicitamente metafísico, na mimese naturalista que tem a natureza como modelo universal, e portanto, na base do simulacro naturalista. Marx transforma este simulacro num modelo operacional que se impõe mediante generalização e universalização à todos os tipos de sociedade. Outro aspecto desses limites situa-se no 
conceito de necessidade, que está na raiz do contraponto do homem com a natureza e na relação entre necessidade, força de trabalho, exploração emancipa tória, onde as perspectivas revolucionárias se apóiam para opor o homem alienado ao homem consciente. Ao deixar de criticar o conceito de necessidade e absorvê-lo como dado, Marx contamina-se pela metafísica da economia política e da ideologia burguesa moderna. Outro núcleo dessas críticas está na fatalidade da transformação revolucionária associada ao desenvolvimento das forças produtivas. Tal determinação não foi efetivada nos movimentos históricos reais e as forças dominantes controlaram as relações sociais do processo produtivo e societário manipulando essas forças ao seu favorecimento;

6) Baudrillard opõe o materialismo histórico e dialético ao perspectivismo radical de Nietzche, porque considera os conceitos modo de produção e produção, conceitos-signos que transformam a natureza em simulações referenciais. Bruzzi de Melo a este propósito, identifica na tese de Baudrillard, que a contrapartida ao simulacro positivista está contida na psicanálise "nos conceitos de Lei, Inconsciente e Interdição". A castração emerge como o pagamento da dívida simbólica rompida, com a troca, através do Inconsciente; e, o recalcamento, como resultado da liberação do inconsciente através da Interdição. Freud e Marx, no plano da análise de Baudrillard, desvelam-se sob o jogo dos significantes como conteúdos de interpretação que partem de princípios abstratos; no caso de Freud, ainda inscritos na ordem do valor e no domínio da moral.

7) $\mathrm{O}$ antropocentrismo cristão tem como gênese a anti-phisis judeu-cristã: corpo e alma pertencem, respectivamente, aos reinos da natureza e de Deus. Por isso o homem, que pertence aos dois reinos é superior pela ascendência sobre os outros seres. "Cristianismo e marxismo unem-se contra o paganismo e o animismo, os quais estabelecem essa rígida separação entre o animado e o inanimado". Por conta dessa cisão a ciência pode desenvolver-se; o cristianismo provoca um distanciamento do mundo dando dimensão teórica mais ampla ao pensamento social. $\mathrm{Na}$ racionalidade grega esse desenvolvimento foi impedido porque seus conceitos de razão estavam ligados à natureza.

A leitura psicanalítica de Marx e Weber realizada por Baudrillard indica uma evolução do modelo de exploração intensivo e racional do cristianismo sobre a natureza, para completar-se na ética do trabalho. Esta ética, de natureza puritana, justifica o enfrentamento do cristianismo contra 
os contestadores de sua teologia, os hereges, panteístas, naturalistas, milenaristas. "A passagem das práticas ascéticas às práticas produtivas corresponde a substituição de um processo de sublimação repressiva, por um processo de "dessublimação regressiva", expresso na ética antropocêntrica do protestantismo "[.] (cf. Bruzzi de Melo, pp. 41- 49)".

\section{III- GRANDES RELATOS E "METAFÍSICA SOCIOLÓGICA": princípios da racionalidade e da irracionalidade "científica" no debate da Legitimação e da Hegemonia no pensamento metateórico.}

O pragmatismo pós-moderno descarta a hipótese de que o pensamento social possa realizar-se fora da divergência. $O$ diálogo entre perspectivas opostas é um estado dessa pragmática, cuja ênfase na desconstrução dos grandes relatos (les grandes récits) não busca o consenso nem a eleição de um novo paradigma. O consenso é inatingível na diversidade de posições intelectuais pós-industriais e pós-modernas; um paradigma novo apenas estabilizaria a intelecção em torno de uma idéia para a produção de PARALOGIAS, de falsos raciocínios. A crítica dos grandes relatos reflete, em grande ponte, aspectos discutidos no processo de formação da sociologia: a complexidade das sociedades e o desenvolvimento do individualismo nas sociedades pós industriais são características que Durkheim, Tocqueville, Parsons, Marx e Simmel referiram-se em diferentes variações quando as modernas sociedades industriais emergiram. Durkheim enfocou questões normativas e éticas do indivíduo na diferenciação da solidariedade orgânica, da função dessa diferenciação na coesão social e na produção do egoísmo anômico, qualitativamente diferente das semelhanças das sociedades segmentárias simples; o espaço privado foi abordado em Tocqueville no desenvolvimento do indivíduo moderno europeu, dos direitos individuais pleiteados pela nova forma republicana de poder separada do espaço público; Simmel e posteriormente Parsons enfocaram o desenvolvimento de relações universalistas e afetivamente neutras; Marx, na inspiração de Darwin, segundo a avaliação de Boudon e Baurricaud (...) refere o isolamento de indivíduos decorrente de sua competição no mercado. No quadro dos grandes relatos, os exemplos das noções de indivíduo não estavam descoladas das concepções e do quadro conceptual das abordagens clássicas; apesar de a diversidade de avaliação do fenômeno variar de autor para autor, há uma clara relação entre egoísmo, desenvolvimento do 
individualismo e complexidade social como consenso entre os autores clássicos que pode advir da oposição que diferenciava as sociedades tradicionais e as sociedades industriais (Boudon e Borricaud, 1993, pp. 286288).

Assim, desde essa época há questões da ética e da política que opõem tendências sobre a uniformização da sociedade e as tendências pela diferenciação e à autonomização dos indivíduos. No plano metodológico, o individualismo pré-clássico e clássico da Sociologia pode ser interpretado de modo tão pluralista em perspectivas quanto a variedade que a crítica pósmoderna faz dos paradigmas ou referências teórico-metodológicas da Sociologia das Luzes. Simmel, p.ex., ilustra esse pluralismo ainda no âmbito do diálogo e da crença na Razão: as possibilidades de enunciação e de objetividade filosóficas são múltiplas; a pluralidade está na origem do seu pathos filosófico; os enunciados plurais constituem-se em um objetivo final; em um fim em si; (...) “o sentido do relativismo está em por em dúvida a validez absoluta das possíveis enunciações particulares” (Simmel, 1994, pp. 205-206) e, este sentido é totalmente livre da questão de saber se a imagem que se tem do mundo é monista ou pluralista. Nele, a natureza absoluta de cada enunciado é fundamental, necessária, incondicional para suas análises. No entanto Simmel não crê que possa haver uma posição a priori do mundo capaz de alcançar a totalidade da vida; e apesar disso, cada posição oferece um aspecto necessário, prioritário sobre uma dimensão ou nuance da totalidade, sem invalidar em cada uma a importância de sua esfera de atenção (Lukács, 1994, pp. 200-209).

Esta alusão ao pluralismo no pensamento social moderno não tem o propósito de desqualificar os enfoques e questões abordados pela Sociologia pós-moderna, em sua crítica aos clássicos. Trata-se de pôr outros termos em relação à "legitimação" da ciência ou da "hegemonia" de um pensamento social sobre outro na própria "oposição" que os teóricos pós-modernos delimitaram. Alguns posicionamentos podem parecer inovadores quando, na verdade, por exemplo, as ilusões ao irracional emergem como um dos aspectos negativos do que é desconhecido, do que não consegue ser explicado ou do que ainda não pode ser apreendido porque ainda é um processo emergente, um fenômeno episódico ou as suas articulações, ainda não foram desvendadas. A importância de uma crítica teórica consiste em questionamentos acerca dos componentes de sua estrutura, da "congruência entre teoria e observação", da descoberta de "explicações tautológicas", dos julgamentos arbitrários "contidos em determinadas 
proposições; (...) "a crítica se interroga, especialmente, sobre a existência de fatos que se podem opor à teoria ou que a teoria não justifica” (Boudon, Borricard, pp. 340-341)". Isto faz da metodologia uma dimensão especial e de importância vital para o sociólogo e para o pensamento de todas as ciências, e, supõe, para evitar o risco da criação de oposições entre dogmatismos, "um treinamento prolongado na explicação de texto" (op. cit, 1993, 341).

Nas ciências sociais, de modo particular na sociologia, as críticas teóricas são vistas, de um lado, pelo fato de elas constituírem-se em torno de uma sensibilidade maior às perspectivas do pensamento social; e, de outro lado, pela dispersão e amplitude de envolvimentos institucionais, de projetos de pesquisa, de fragmentação de suas comunidades em grupos temáticos, da dificuldade de interlocução e acompanhamento dos debates em todos os aspectos e campos abertos pelo pensamento social. Essas condições justificam e repõem a necessidade de estudo que passam pelos momentos de críticas e rupturas desse pensamento e de sua relação com as tendências científicas contemporâneas e, especialmente pela caracterização alusivas às metateorias como "metafísica sociológica" que, simultaneamente, repõem críticas aos grandes relatos, à oposição de princípios "racionais e irracionais" e à crise de legitimação/hegemonia do pensamento sociológico (meta e supra teórico e histórico).

"É possível resumir a partir de 1968, na produção sociológica americana, anglo-saxônica e francesa, as reestruturações teóricas mais contundentes e notáveis, sob a forma de uma crítica de maior densidade ao modelo cultural das 'sociedades de consumo", da perda da legitimidade desse modelo, através da negação de "paradigmas" anteriores e explosão de "novos paradigmas". No caso americano, a hostilidade ao funcionalismo marcou o fim da hegemonia parsoniana na produção intelectual provocada pelas demandas do Estado e das lutas sociais, que por sua vez derivaram-se de uma crise social de anos anteriores que permitiu a expansão do campo institucional do sociólogo e a implantação de uma infra-estrutura pública gigantesca que atingiu, entre 1970-1973, 120 milhões de dólares, lobistas profissionais; a ASA organiza mais de 20 comitês e o número de seus membros dobrou em menos de dez anos para 15.000 (Cuin e Gresle, 1994, 248-249). Essas demandas episódicas reverteram-se em uma crise inflacionaria, de segmentação e de desagregação da sociologia como disciplina, com conseqüências internas no campo científico. As demandas oficiais que conferiram legitimidade ao funcionalismo e hegemonia ao 
pensamento de Parsons, ao desaparecerem, implodem o estatuto teórico de ambos com a multiplicação de paradigmas hostis à esse quadro de referência. A crítica que se inaugura a partir de Alvin Goudner, "de natureza marxizante", toma como núcleo o envolvimento institucional da Sociologia com as políticas de governo, "os escritórios de futurologia" disseminados como campos de aplicação sociológica em problemas da organização social americana (sistema carcerário, escolar ou de saúde), os excessos contidos pelo trabalho profissional de sociólogos contra lutas sociais, de natureza revolucionária, dentro e fora da sociedade americana, que situam essa perspectiva crítica no contexto ideológico da escola de Frankfurt. Desta configuração, pode dizer-se que a "teoria crítica americana" que demoliu a legitimação científica do funcionalismo e do pensamento parsoniano guarda relação com a sociologia clássica, atualizando-a frente a questões contemporâneas da realidade social. A crítica ao pensamento de Parsons permitiu, em outro âmbito, a substituição do status sociológico behaviorista pelo "interacionismo simbólico" que reformulou o pensamento de "escola de Chicago" pela ênfase em pesquisas sobre fenômenos do desvio e divergência social, tomando a observação participante como metodologia predominante (Goffman, Becker, Garfinkel). Várias derivações da superação da hegemonia parsoniana apresentaram-se na produção sociológica norteamericana. A teoria da "etiquetagem" (Lemert, Matza), o modelo "dramatúrgico", que constitui a análise de situações limite que ameaçaram os atores sociais tais quais os riscos de administração da distância entre a identidade "real" e a "virtual" e que constitui a crise de uma concepção liberal de sociedade americana; e, a corrente "etnometodológica" como uma radicalização do interacionismo simbólico, uma vez que a própria ordem simbólica torna-se contingente (Berger e Luckman), e as formas de compreensão são substituídas por conceitos de reflexividade e de descritibilidade- que Cicourel denomina de "um relatório dos relatórios". A etnometodologia, apesar das críticas expande-se na Inglaterra, na Alemanha, na França, com recursos lingüísticos e extralingüísticos, preocupada com a "indexibilidade" dos contextos, ou seja com os efeitos deste sobre a "coerência e a inteligibilidade" dos intercâmbios verbais. (Cuin e Gresle, pp. 251-255).

Outra conseqüência da ruptura teórica com o funcionalismo e a crítica ao pensamento parsoniano foi o surgimento das teorias de intercâmbio social (onde os indivíduos em interação são guiados racionalmente pelo cálculo entre perdas e ganhos), onde a presença ou ausência do equilíbrio entre as retribuições e contribuições sociais provocaria 
a satisfação, o conflito e a "frustração relativa" (Runciman, Hirschman, Blau, Goode). Derivações desse intercâmbio no plano das instituições enfocaram o prestígio e a distribuição do poder no âmbito de "normas de reciprocidade" que resultaram em teorias neo-utilitaristas da "escolha racional" ou do “individualismo metodológico” (Heath, Elster, O’Neill) que, apesar de apresentarem, de um lado, "um estágio pré-sociológico" de concepções de ação social, apresentaram, de outro lado, uma penetração significativa no campo da sociologia política e da sociologia de ação coletiva "enriquecidas pela teoria econômica e pela teoria dos jogos". (Cuin e Gresle, 1993, p.256).

A sociologia anglo-saxônica nos fins dos anos 80 está constituída de considerável segmentação institucional, intelectual e temática "o que lhe confere uma riqueza potencial para seu desenvolvimento extensivo" (Cuin e Gresle, 259). Há, no entanto, um conjunto de problemas que limitam qualitativamente o incremento da disciplina relacionados à inadequação entre o grande volume de recursos e os resultados da pouca intensidade qualitativa: a pesquisa empírica de caráter indutivo predomina, ainda, apesar da variedade de recursos teóricos; os trabalhos teóricos "são de um formalismo abstrato" e de pouco valor histórico; as pesquisas de campo com freqüência, são generalizações empíricas de difícil integração aos saberes constituídos, contrários ao credo incrementalista que acredita na acumulação de dados como um caminho seguro para a extensão do conhecimento. A relação com empirismo também ainda é muito grande gerando entre outros efeitos perversos (...) "a construção nominalista de fatos que devem muitas vezes sua esfericidade, ou até sua existência aos métodos de acordo com os quais são observados e analisados; a identificação da cientificidade e do valor cognitivo dos resultados com o rigor e a sofisticação das técnicas; convicção da neutralidade axiológica dos produtos da formalização matemática; enfim - como a necessidade dos métodos estatísticos é lei - concepção individualista de fenômenos estruturais" (Cf. Cuin e Gresle, p. 259) .Uma outra vertente da Sociologia anglo-americana vem se dedicando a grandes sínteses teóricas que integrem o pensamento clássico - "da etnometodologia ao marxismo", em uma diversidade de formulações teórico-metodológicas.

Os anos 70 extinguiram, no final da década, a hegemonia do estrutural-marxismo francês e, novas orientações teóricas predominariam nas décadas seguintes, em torno de interesses pela diacronia, pela ação, pelo local com arrefecimento do debate teórico-ideológico. O fim da hegemonia do estruturalismo francês após 30 anos de predomínio, caracteriza, também o fim de uma possibilidade de análise que, dando destaque a uma filosofia 
idealista, desenvolvia uma análise da dominação das estruturas sócioeconômicas onde o indivíduo não é mais o sujeito da história, nem de suas articulações, mas são portadores de estruturas e, neste sentido, tornam-se suportes dos processos e mecanismos de reprodução. Esta corrente teórica tematizou o Estado e a política, o sistema escolar, a cidade e o urbanismo, com nomes proeminentes que, ainda hoje são prestigiados por suas contribuições intelectuais na criação de um "avatar marxizante de um estruturalismo nas ciências humanas". Lèvi-Strauss, Lacan, Barthes, Foucault, Althusser, Poulantzas, Bertaux, Castels e outros. As noções de aparelho de Estado, burguesia e de estrutura de classes eram conceitoschaves deste enfoque do controle da dominação e da reprodução social. A repercussão do estruturalismo francês fora da França (Inglaterra e América Latina) mantém a audiência intelectual desta vertente. Na França, no entanto, fechou-se intelectual e politicamente por suas perspectivas de análise e à conquista do poder pela esquerda.

Hoje, as referências teórico-metodológicas da Sociologia Francesa dividem-se em quatro grandes "paradigmas" cujas variações internas não são tão volumosas quanto as da Sociologia norte-americana, mas permitem a identificação de diferenças de abordagem. É importante registrar a hegemonia ou predominância, em todos os enfoques, da noção, do conceito, da categoria, da unidade social configurada no ator, no átomo, no "estratego" como diferentes formas de posicionamento do indivíduo na sociedade, em termos mais atuantes na ação social (Bourdieu) ou de representante, executor ou formulador, no sentido estratégico, do jogo institucional, como indivíduo ou como ator coletivo (Michel Crazier), o último com interesses, projetos e auto-reconhecimento definidos em termos de transformação de uma ordem" transcendente" a ele - na visão de Bourdieu-, na qual a sua ação mais conseqüente é a capacidade de negociação, de geração de acordos. As referências teórico -metodológicas delimitam-se no estruturalismo genético, no accionismo, no modelo estratégico, e no individualismo metodológico. As noções-chaves constituintes desse pensamento social são os processos e estruturas sociais condicionantes, reproduzidas e produtoras dos comportamentos individuais, a capacidade de ação sobre si próprias das sociedades pós industriais, a historicidade como sistema de ação social, o lugar das organizações na vida social e a "intencionalidade" e racionalidade dos atores individuais (cf. Cuin e Gresle, pp. 260-269). 
À despeito de essas formulações possuírem meios, recursos, e perfis próprios do ponto de vista axiológico é possível dizer que há aspectos epistemológicos que constituem o discurso da sociologia clássica minimizados mais inconfundíveis. A "legitimidade" acadêmica e institucional extra-acadêmica da nova Sociologia Francesa deve muito aos pensadores modernos que alimentam suas polêmicas, tanto em termos de originalidade e alcance de prestígio interdisciplinar e societário, como em termos de antecipação de problemas e temáticas que se configuraram por inteiro na atualidade.

A ciência social tratada como gênero de linguagem deixa a Sociologia pós-moderna a vontade para reinventá-la e reinscrevê-la nas relações de dependência com a ética e a política apesar de os clássicos modernos terem-na emancipado de todos os outros condicionamentos não racionais. Verdade e Justiça repõem a legitimação da ciência ao juízo da explicitação de suas regras, dos procedimentos, das condições de aplicação- experimentos e consistência interna-, a partir de conjuntos de enunciados que postulem reconhecimento, traduzíveis num discurso a consideração da comunidade de interesse científico. Esta forma de institucionalização inclui um jogo de articulação com outras linguagens da sociedade pós-industrial e pós-moderna que atinge, diretamente, a natureza da criação, da inventividade, e da imaginação, e, exige sua tradutibilidade e utilidade "para eventuais usos de linguagem de máquina" (cf. Lyotard, p.4). Há um campo de conhecimento hegemônico, o cibernético- informático- informacional que torna dispensável as relações entre formação do saber e a formação do espírito, para transformá-las em relação de fornecedores, usuários e, o próprio conhecimento em relações mercantis entre produtores de conhecimento e os consumidores de mercadorias; o saber científico assume sua forma valor (cf. Lyodard, p.4, Baudrillard, op. cit.).

A ciência desde Marx estava ligada à concepção do desenvolvimento das forças produtivas. Sua tradução em tecnologias e em técnicas de incremento econômico alterou o poder de articulação e de imposição de estados-nações, até o ponto em que a cientificidade da organização racional da empresa superou a capacidade de domínio dos governos sobre os territórios, matérias primas, mão-de-obra, quando as multinacionais e transnacionais passaram a operar uma estratégia de racionalização do capitalismo em escala internacional e mundial. 
Ainda que a difusão e a produção do conhecimento científico tenha saído do controle institucional do Estado, os desenvolvimentos da criação e da aplicação da ciência exigem, elas próprias, interferências estratégicas de fomento públicos mediatizados por políticas governamentais, no sentido de que a detenção do saber seja impulsionadora do bem-estar e da riqueza social. Se, por outro lado, o Estado torna-se rígido e opaco a ponto de impedir a fluidez, a transparência e a operatividade para a circulação das informações científicas fundamentais para as estratégias produtivas, industriais,comerciais, financeiras e militares, por certo estará posto "um problema das relações entre as instâncias econômicas e as estatais" (Lyotard, op.cit., p.6). Tais problemas podem resolver-se sob a forma de cisão ou de subsunção do Estado à esfera da economia, em caráter amplo e irreversível. Diante dessa circunstância, o saber/ignorância será apreciado no plano "conhecimento de pagamento / conhecimento de investimentos" e será posto em circulação sob a forma moeda; e, todo trabalho científico será organizado e controlado conforme o desempenho, a performance, a eficácia, a eficiência, os resultados que os programas apresentarem ao controle social.

O conhecimento científico como base das forças produtivas já estava delineado nas análises de Marx sobre o desenvolvimento capitalista. Da mesma forma, Max Weber já desvendara nos processos sócio-culturais, de vários tipos e circunstâncias históricas, que o desenvolvimento da ciência no Ocidente se efetivara sob a forma e o vulto em que o saber institucionalizado racionalizara-se, no sentido de ampliar e consolidar-se sob um tipo peculiar de dominação burocrático-racional, resguardado, até certo ponto, de outras obrigações da ordem política e econômica. Se no marxismo a transformação da ciência em força produtiva passava pela engenhosidade da tecnologia, pela sua transformação em máquina, "força de saber objetivada", em Weber a separação da ciência dos interesses políticos e econômicos tornava fundamental o asseguramento de ordens diferenciadas de racionalização: as ações políticas e econômicas circunscrevem-se no plano dos interesses e as ações da ciência no plano axiológico sem a pretensão objetivista das ciências da natureza. As vocações científica e política pertencem a diferentes ordens de interesses e de dominação. Há nessas vocações implicações de escolhas éticas entre as convicções e as responsabilidades que, no fundo, articulam uma fronteira entre ciência e política, mesmo com as restrições das diferentes variações, porque há um processo de escolha. O progresso científico, fragmento do progresso de intelectualização milenar deve à ciência e à técnica essa racionalização intelectualizante que dá à ciência um lugar diferente no plano do conhecimento. Se não é uma universalidade que 
distingue o conhecimento científico dos outros é, então, uma atitude diante do conhecimento que configura a posição científica de outros saberes: a certeza de que pela crença ou pela vontade portam o poder de previsibilidade e de probabilidade de dominar, no sentido de controlar, o curso dos acontecimentos, o que equivale a despojar a magia do mundo (Weber, 1988,29-30).

A ciência é elemento e motor do desencantamento e tem o significado de não atingir um ápice diante do processo civilizatório; esse objetivo inatingível de "estar pleno de civilização é impossível”. A ausência de sentido da morte está relacionada à ausência de sentido da vida do civilizado, onde o homem está ao meio do caminho de uma civilização permanentemente enriquecida de pensamentos, problemas, experiências (cf. Weber, pp. 30-31). O sentido da vocação científica para o cientista perde predominância diante da questão do "significado da ciência no contexto da vida humana e de qual o seu valor para a sociedade moderna”. Entre o passado antigo e o presente moderno operou-se uma transformação considerável no significado da ciência, na expectativa e na atitude dos homens modernos diante dela. Os prisioneiros da caverna de A República, na alegoria de Platão sobre o conhecimento clássico estavam condenados a viverem de costas para a luz, ocupando-se das sombras projetadas na parede à sua frente, sem poderem examinar outra coisa senão o movimento e as relações das próprias sombras. Um desses prisioneiros se solta e encara o sol entre deslumbrado, desorientado,desnorteado, sem conseguir falar alguma coisa e escolher um caminho à seguir. Ao acostumar-se ao contato com a luz.e a partir dessa experiência, ele assume consigo próprio o compromisso de voltar à caverna para conduzir os outros prisioneiros ao ato de encarar o sol. (...) "Ele é o filósofo e o sol representa a verdade da ciência, cujo objetivo é o de conhecer não apenas as aparências e as sombras, mas também o ser verdadeiro" (Weber, p. 32).

A realidade social dita pós- industrial e pós-moderna promove, através de seus pensadores, rearranjos de temas e de problemas que repõem questões da emergência e da transformação das Ciências Sociais, no quadro contemporâneo. Uma incontestável predominância, no entanto, existe nos campos econômico e cultural, em escala planetária dos fenômenos de massa das relações sociais, crescentes e insólitas em vulto e em complexidade, no envolvimento das relações com a ciência, a técnica, a organização institucional dos poderes, da vivência de grupos, indivíduos, coletividades e Estados. Weber, em seu tempo, dava-se conta de que aos olhos do homem 
moderno, especialmente dos jovens, a confiança na ciência estava no sentido inverso do entusiasmo filosófico da época grega: a ciência lhes parece irreal, as construções intelectuais são abstrações incompreensíveis, apesar dos esforços do conhecimento para apreender a especificidade dos sentidos da ação social. A vida social está mais próxima das sombras da caverna de Platão, assemelhando-se mais à um jogo projetado e é nele que está contida a realidade verdadeira. $\mathrm{O}$ entusiasmo pela ciência que parecia ter encontrado na razão filosófica e científica um caminho irreversível não parece seguro na expectativa do jovem moderno. Os gregos, ao contrário, estavam inebriados com a descoberta do conceito, do sentido de sua importância para o conhecimento científico - Sócrates, outros escritores orientais, Aristóteles, enfim, o pensamento ocidental soube apropriar-se da lógica e do modo de ela apropriar-se da vontade do indivíduo, até que ele se curvasse à superioridade do princípio que encerra a verdade eterna, como meta a ser perseguida para a superação contínua da ignorância humana, e para o aprimoramento da sua experiência de vida. O Belo, o Bem, a Alma, a Coragem foram conceitos que os gregos impulsionaram para atingir a compreensão e criar condições de ensinar a convivência entre os semelhantes, entre os cidadãos, criando ao mesmo tempo uma contribuição à organização humana categorizando fenômenos da vida política (Weber, cf., p.33).

A experimentação racional, outro grande evento da ciência, emborca conhecida na Índia e na Antigüidade helênica através de experiências fisiológicas e matemáticas assume um princípio investigativo como meio de controle da pesquisa, no Renascimento. A arte verdadeira, a verdadeira natureza, seria viabilizada por um caminho que emergira da modernidade no Ocidente. Hoje, diz Weber, é o contrario que parece ser o caminho da verdade. A libertação da prisão científica propiciará o verdadeiro encontro do homem com as suas propriedades naturais. A ciência é o conhecimento passível de eliminar qualquer crença de que seus conhecimentos possam ensinar alguma coisa sobre o sentido do mundo ou a encontrar sinais de que este sentido existe. A ciência não pode conduzir à vida terrena nem à divina; contrariamente, "o pressuposto fundamental de qualquer vida em comunhão com Deus impele o homem a se emancipar do racionalismo e do intelectualismo da ciência; essa aspiração ou outra do mesmo gênero, erigiuse em uma palavra de ordem essencial, que faz vibrar a juventude alemã [.] ... Só parece desconcertante, dentro desse gênero de aspirações, o método escolhido, no sentido de que o domínio do irracional, único domínio em que o intelectualismo ainda não havia tocado, tornou-se 
objeto de uma tomada de consciência que é minuciosamente examinado. À isso conduz, na prática, o moderno romantismo intelectualista alemão do irracional. (Weber, p. 35).

A antecipação do resultado aos que procuraram livrar-se do intelectualismo pelo caminho da irracionalidade não difere muito, também, daqueles que ingenuamente celebram a ciência com um otimismo exagerado - "ou celebraram a técnica do domínio da vida fundamentado na ciência"como o caminho que levará à felicidade. É, para eles que Weber recorda Nietzche, em sua crítica "contra os últimos homens que descobriram a felicidade". Excetuando certas crianças grandes em cátedras de faculdades

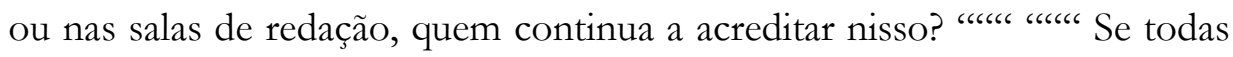
as ilusões já estão destruídas e elas vislumbravam caminhos "à verdadeira arte", “à verdadeira natureza", “ao verdadeiro Deus" e" à verdadeira felicidade", qual é o sentido da ciência enquanto vocação? Ao responder as indagações típicas de seu tempo com Tolstoi, Weber insiste em que ela não tem sentido, não indica o que deve ser feito, nem a forma de vida melhor para ser vivida. (...) Permanece apenas o problema de saber em que sentido a ciência não nos proporciona resposta alguma e de saber se a ciência poderia ser de alguma utilidade para quem suscita corretamente a indagação (cf. Weber, pp. 35 -36).

A questão da legitimação da ciência em Weber é clara diante de uma outra visão presente nesse debate, que é a da existência de uma ciência sem pressupostos. Para ele o sentido das palavras postas na pergunta orientarão a decisão de aceitar ou recusar um valor que não pode ser demonstrado em "sua existência em si". Sua posição particular é a de que "todo trabalho científico pressupõe a validade de regras da lógica e da metodologia, que constituem os fundamentos gerais de nossa orientação no mundo" (op.cit., p. 36). No entanto, a tradução de uma escolha na diversidade de campos científicos é uma tarefa impossível pela ausência de demonstração de em que consiste uma "vocação", um "valor em si", nem provar que o conhecimento científico produzido merece existir, se tem ou não sentido, enfim, questionamento que se põem para alguns campos de conhecimento. Para outros, há pressupostos gerais que nem sempre estão isentos de problemas como os que são postos para a Medicina.Nas disciplinas da arte, a estética por exemplo, a proposta é a de pesquisar a gênese da obra de arte; não é posta a pergunta se deveria haver ou não obra de arte, em razão de dúvidas religiosas, preconceituosas, etc. O direito é uma outra disciplina que orienta para sua validade segundo as regras da doutrina da ciência do Direito, parte 
lógica, parte factual, dadas pelas convenções mais com métodos e regras de interpretação tidos como obrigatórios, mas não responde se deveria existir uma consagração de normas que correspondessem a um determinado tipo de Direito que deveria existir. Na História não cabe responder se tais ou quais fenômenos mereceriam ter acontecido ou existido (cf. 36-38).

Nas ciências interpretativas, àquelas que tem por objeto a interpretação de todos os tipos de conhecimento das disciplinas Sociologia, História, Economia Política, "e todas as espécies da filosofia da cultura, existe sempre o risco de os instrumentos de análise científica do pesquisador, do professor, serem distorcidos por questões políticas da conjuntura e pelas posições políticas dos alunos, porque os métodos provocadores dos raciocínios, estimulados pela explicação da própria ciência, permitem a condução do aluno até o ponto onde ele possa fazer o discernimento do fenômeno em análise, seja pelo seu contrário, seja mediante uma escolha guiada" pelos seus ideais básicos". Ao professor consiste apresentar os conteúdos e treinar a acuidade interpretativa dos ouvintes para o rigor metodológico; a probidade intelectual exigida para quem manipula, através dessas disciplinas, duas ordens de problemas complexos, relacionados e heterogêneos que deverão ser reconhecidos é também uma necessidade para a distribuição clara dessas mesmas ordens:

1) (...) o estabelecimento dos fatos, a determinação das realidades matemáticas e lógicas ou a identificação das estruturas intrínsecas dos valores culturais [;]

2) e, de outra parte, a resposta a questões concernente ao valor da cultura e de seus conteúdos particulares ou a questões relativas à maneira como se deveria agir na cidade e em meio a agrupamentos políticos "(cf. 39).

Em Weber, a exclusão de questões da ação e da decisão política da sala de aula, que preocupam e são objeto da atuação do profeta e do demagogo, são problemas que, ao serem postos pelo professor que tem a legitimidade do saber perante os alunos "condenados ao silêncio", tornamse o oposto do dever do professor - que é o da transmissão de conhecimento e da experiência científica-, tanto quanto "o profeta e o demagogo estão deslocados em uma cátedra universitária".

Em resumo, a questão da legitimação de ciência envolve, também, decisões no plano ético, tanto no compromisso político quanto da vocação científica porque elas não estão fora do âmbito do dever. Ao homem dedicado à ciência, no entanto, essas questões axiológicas têm a ver com seu 
próprio trabalho ; ou seja, Weber propunha apresentar condições de provar que quando um cientista deixava-se levar pela manifestação de seus próprios juízos de valor ele perdia a compreensão integral dos fatos (cf., p.39). Aqui se impunha a distinção entre a "fé" e o conhecimento "sem pressuposto", ambos de natureza ética aproximada, com critérios de avaliação e métodos diferentes. Ao crente seria muito improvável a aceitação da interpretação científica da gênese e desenvolvimento das formas de religiosidade; ao cientista essa discordância da visão da fé está na condição de a ciência não submeter-se à autoridade religiosa, nem reconhecer milagre ou revelação (cf., p.40).(...) “À ciência sem pressuposto" exige do crente nada menos - mas, igualmente nada mais - que a cautela de simplesmente reconhecer que, se o fluxo das coisas deve ser explicado sem intervenção de qualquer ordem dos elementos sobrenaturais a que a explicação empírica recusa caráter causal, aquele fluxo só pode ser explicado pelo método que a ciência se esforça por explicar. E isso o crente pode admitir sem nenhuma infidelidade a sua fé" (Weber, op.cit., p. 40).

Esses argumentos auxiliam a esclarecer que, no plano da produção e da interpretação científica dos fenômenos históricos e sócio-culturais existem razões que justificam um distanciamento da prática de decisão em questões de valores e, consequentemente, justificam a recusa pela imposição de convicções pessoais. Há, no entendimento weberiano, porém, outras razões profundas: a diversidade de valores defrontam-se incessantemente no mundo prático, opondo os deuses das diferentes ordens . Recorrendo à filosofia de Mill, Weber apresenta "a fórmula paradoxal e superficial" desse confronto, referido desde a Bíblia: (...) "uma coisa pode ser santa não apenas sem ser bela, mas porque e na medida em que não é bela - e a isso há referências no capítulo LIII do livro de Isaías e no salmo 21. Semelhantemente uma coisa pode ser bela, não apenas sem ser boa, mas precisamente por aquilo que não a faz boa" (p.41). Weber, segundo diz, acompanha Nietzche e Baudelaire, também interpretes da sabedoria popular, que "uma coisa pode ser verdadeira, conquanto não seja bela, nem santa, nem boa". Esses exemplos simples são amostras da oposição dos diferentes valores divinos, de diferentes éticas que se opõem, e não há base científica para demonstrar que um valor é superior ao outro: os sacrifícios dos gregos romanos aos deuses particulares e das cidades-estados, as éticas de não oposição ao mal ou ao Sermão da Montanha encerram, aos que optam pelo sagrado ou pelo profano, ou que optam por estudá-los, um limite de escolha em decidir entre o destino que governa os deuses e a compreensão do significado do divino para determinada sociedade, ou os diferentes sentidos 
e tipos de fenômenos considerados divinos. Isto põe outra questão: o racionalismo que a civilização ocidental desenvolve subjaz, inclusive, a orientação ética das decisões e, neste plano, as escolhas apontam uma direção única "destronando" o politeísmo, transformando a religião, à partir do cristianismo, numa "rotina quotidiana". Os deuses antigos abandonam suas tumbas e, sob a forma de poderes impessoais, porque desencantados esforçam-se por ganhar poder sobre nossas vidas, reiniciando suas lutas eternas. Daí os tormentos do homem moderno, tormentos que atingem de maneira particularmente penosa a nova geração: como se mostrar à altura do cotidiano? Todas as buscas de "experiência vivida tem sua fonte nessa fraqueza, que é fraqueza de não ser capaz de encarar de frente o severo destino do tempo em que se vive" (Weber, pp. 42-43).

A crise dos paradigmas nas ciências sociais ao duvidar da Razão configurou-se como uma polêmica intelectual multidirecionada, gerando ela própria, pela diversidade ou pela forma de condução das críticas, uma revisão dos clássicos, amplas sínteses teóricas que os integrem na reflexão dos fatos e processos sociais contemporâneos e, ainda, tentativas de "relegitimação" do pensamento clássico aberto à incorporação de novas técnicas e métodos de investigação. Alguns aspectos já se delineiam como consensuais: sobre a arbitrariedade da divisão entre os fenômenos sociais das micro e macrosociologias; a oposição artificial entre os pontos de vista das estruturas e da coerção e o ponto de vista dos atores e da subjetividade; a esterilidade do debate da crise dos grandes pelos pequenos relatos, ou dos pequenos relatos em si próprios; a necessidade de reatircular o pensamento social na configuração de conceitos e de categorias que alcancem a envergadura dos fenômenos que desafiam os intelectuais do fim do século XX.

A crítica ao pensamento clássico, tanto as de natureza tópica quanto as de maior abrangência, incidem na questão teórica de Marx e Weber, no caso enfocado deste trabalho, como METATEORIAS e METAFÍSICA SOCIOLÓGICA que, à nossa apreciação podem enquadrar-se na multiplicidade de sentidos que a própria noção de teoria recebe das ciências sociais, que Merton classificou em "Social theory and social struture", como:

1) Metodologia; 
2) idéias diretrizes;

3) análise dos conceitos;

4) interpretações "pós-factum";

5) generalizações empíricas;

6) derivação (dedução de colorários decorrentes de proposições já estabelecidas) e codificação (busca por indução de proposições gerais que permitam subsumir proposições particulares já estabelecidas).

7) teoria stricto sensu (cf. Boudon e Bourricaud, 1993, pp. 558-560)

Essa classificação de Merton guarda certa relação com a crítica pósmoderna à Sociologia Clássica, porque no sexto e no sétimo caso, conforme resumiram Boudon e Bourricaud, os conceitos de teoria em sociologia aproximam-se mais às acepções de teoria stricto sensu e a de paradigma. Mas, é exatamente no entendimento de paradigmas desses autores que está posta a questão de metateorias no exemplo em que a análise funcional de Merton é enquadrada. Este enquadre comportaria o alcance das formulações dos pensamentos de Marx e de Weber? Para Baudrillard e outros intérpretes menores, a teoria marxista construiu análises funcionais, no sentido em que nada mais se fez do que classificações de um discurso, composto a partir de teorias existentes sobre a realidade social, e não sobre os fatos mesmos desta realidade. Na condição de metateoria é mais um paradigma do que uma teoria stricto senso, porque contém um conjunto de enunciados, em procedimentos metodológicos indicadores do modo de como construir a formulação teórica para a explicação de aspectos da realidade. A linguagem da enunciação e do procedimento é mais enfatizada no discurso metateórico do que a realidade empírica em exame. Uma teoria stricto sensu, por seu lado, compõe um sistema formado por proposições, articuladas sob um encadeamento lógico interno, condição que permite, em princípio, raciocínios dedutivos e possíveis confrontações com a realidade.

A "metafísica sociológica" como metateoria poderia, também, na ilustração supra referida, ser classificada no conjunto dos paradigmas formais que incluem tanto as enunciações semânticas e sintáticas do discurso metateórico quanto as relações de interdependência das proposições e de suas variáveis, da circularidade e da causalidade de suas articulações. No caso de Merton a noção de função preside a análise funcional das instituições; do mesmo modo a análise de sistemas preside as relações entre a estrutura e 
função ou entre instituições e um sistema social, ou as características da intertextualidade que indicam a presença de um estruturalismo lingüístico. A dialética materialista também se insere nesse "paradigma formal" pelo fato de conferir "um poder explicativo fundamental às contradições na análise dos sistemas e processos sociais" (cf. Boudon e Bourricaud, op. cit., pp.261).

Questões de explicação e de tipologias, vistas da perspectivas de construções metateóricas, mesmo quando existem recorrências "multivariadas" ("com equações múltiplas, com análise de correspondências ou qualquer outro instrumento estatístico") com ambição empírica de variáveis independentes, na verdade dependem, formalmente deste tipo de paradigma e contém semelhanças de instrumentos e de fundamentos analógicos. Os conjuntos de paradigmas conceituais ou classificatórios, analógicos e formais, tem nas classes que os diferenciam, "zonas de superposição", pontos de intercessão, analogias de formulação, desde a inspiração metafórica até procedimentos assemelhados, ao mesmo tempo em que, enquanto referências, guias para investigação são mais vitais do que descartáveis conforme supõe o exagero da crítica pós-moderna (cf. Boudon e Bourricaud, pp. 261-264).

As referências teórico-metodológicas clássicas resistiram aos vários processos específicos e gerais da produção do conhecimento científico. Como metateoria ou "metafísica sociológica", há um fator positivo que é o de a previsibilidade, a probabilidade, as determinações, a evolução gradual ou por saltos, as contradições lógicas e históricas, as diferentes correntes das interpretações de sentido terem como ponto de partida o social, como fenômeno, processo, estrutura, sistema, relações, tipologias, e, ainda terem uma atribuição metodológica fundamental para a reposição de problemas axiológicos e epistemológicos. As tentativas de ruptura com a filosofia social, com a decomposição do modelo clássico, com a morte e o ressurgimento do sistema e da ação do ator social ainda envolvem problemas formulados na origem da definição da sociologia como ciência. Durkheim inaugura essa temática, nos anos 60 o circulo de Viena (Popper, Khun) retomaram a preocupação com a cientificidade e verificabilidade das Ciências Sociais; os frankfurtianos apreenderam sob a forma de síntese os níveis abstratos e históricos do progresso do pensamento social na fronteira do mundo industrial que se dissolvia para dar lugar à uma racionalidade diversa da que o mundo ocidental orientara para a razão científica. A articulação instrumental do mundo pós-industrial é um dos elementos que pode compor a crítica aos modelos clássicos, pela sociologia contemporânea, ainda em seus 
primórdios. Talvez por isso ainda não tenha a vitalidade suficiente para se impor como um pensamento social autônomo dos processos que constituíram a Sociologia como ciência, embora não possa subestimar-se que, nos marcos contemporâneos, tem tido a capacidade de suscitar questões e reações que expressam uma nova era em curso no pensamento e na realidade. Que, por sua vez, são, também reverberações das teorias de Marx e Weber.

\section{REFERÊNCIAS}

Baudirllard, Jean. - L'echange Symbolique et la mort. Paris, Gallimard/NRF, 1986.

-Le mirois de la production, on l'illusion critique du materialisme historique. $2^{a}$ ed., Paris, Casterman, 1985.

Benjamin, Walter. - Obras Escolhidas. $4^{\text {a }}$ ed., São Paulo, Brasiliense, volume II, 1994.

Boudon, R. e Bourricaud, F. - Dicionário Crítico de Sociologia. São Paulo, Ática, 1993.

Bruzzi de Melo, Hygino. - A Cultura do Simulacro. Filosofia e Modernidade em J. Baudrillard. São Paulo, Loyola, 1988.

.Chalmers, Alan. - A Fabricação da Ciência. São Paulo, Unesp, 1994.

Cavenacci, Massimo. - Dialética do Indivíduo- o indivíduo na natureza, história e cultura. $1^{a}$ ed., São Paulo, Brasiliense, 1981.

Cuin, Charles Henry e Gresle, François. - História da Sociologia. São Paulo, Ensaio, 1994.

Gertz, René E. - Max Weber e Karl Marx. São Paulo, Hucitec, 1994.

Genss, Raymond. - Teoria Crítica e a Escola de Frankfurt. São Paulo, Papirus, Campinas, 1988.

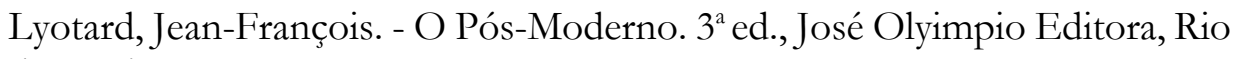
de Janeiro, 1990.

Martin, Alfred Von. - Sociologia del Renascimeiento. México, Fondo de Cultura Económica, 1988. 
Runciman, W. G. - Crítica de la Filosofia de las ciências Sociales de Max Weber. México, Fondo de Cultura Económica, 1976.

Simmel, G.-A Filosofia do Amor. São Paulo, Martins Fontes, 1993.

Weber, Max. - Ciência e Política-duas vocações. São Paulo, Cultrix, 1988. - Economia e Sociedade. Brasilia, Editora UnB, vol.1, 1993.

Fontes, 1993. - Metodologia das Ciências Sociais. São Paulo, Martins 